\title{
DESCRIPTIONS OF SIX NEW SPECIES OF BUPRESTIDA.
}

By H. J. Carter, B.A., F.E.S.

The residence of a keen collector, like Mr. H. W. Brown, at Cue, West Australia, has resulted in the capture of many interesting Coleoptera in this little explored region. Besides a number of new Tenebrionidæ, the following six species of Buprestidæ are undescribed, five of which are from the Cue district.

Chalcotenia violacea, n.sp.

§. Upper surface dark violet, with coppery depressions more or less filled with yellow flocculence. Head with base, mouthparts, under margin of eye, and two basal joints of antennæ coppery, the rest of antennæ piceous red, raised part of forehead violet, central excavation flavo-pulvulose, pronotum and elytra violet on the raised, coppery or flavo-pulvulose on the depressed parts; scutellum blue, underside, femora (except the apex) coppery, albivillose, or floccose, apex of femora, tibiæ, and tarsi blue.

Head with a large scutiform excavation on front, having an interrupted carinate margin, an interrupted medial sulcus, basal part closely, subconfluently punctate, antennæ extending almost to base of prothorax, two basal joints with large punctures, 3rd cylindric, 4-11 serrate and successively shorter. Prothorax $5 \times 6 \cdot 5 \mathrm{~mm}$., subquadrate, subsinuate at base and apex, all angles produced and acute, posteriorly more sharply so and subdentate, sides feebly rounded, converging anteriorly, and faintly sinuately widening behind; disc with wide medial, and two wider lateral sulci, the latter oblique, not at extreme sides, diverging apically to the angles, and narrowly continued on basal line to meet medial sulcus; space between sulci and extreme sides rugosely and irregularly punctate, the sulci finely punctate, the ridges wide and smooth except for a few large punctures. Scutellum transverse, smooth. Elytra wider than prothorax at base, and thrice and one-half as long, posterior sides very finely crenate or 
obsoletely dentate, apex finely rounded; irregularly 5-costate (including the suture), with three intervening sulci, besides a lateral sulcus, and three spots more markedly pulvulose than the rest; these placed, one at base, the second before the middle, at the interruption of the 3rd costa, the third postmedial at the widening of the $3 \mathrm{rd}$ sulcus; all costæ wide, rounded and nearly smooth, the first sutural, the second parallel to first, diverging at scutellum, and not quite meeting the sutural costa at apex, the third starting behind the basal spot, interrupted by a wide antemedial depression, and joining the 2nd costa on the apical declivity, the fourth abbreviated, starting from the humeral swell. ing, narrowed and terminated before the postmedial spot, the fifth starting behind humeral region, terminated on apical border, all sulci and depressions closely and finely punctate, costæ with a few irregular larger punctures. Prosternum sulcate in middle, the sulcus with a coppery carinate margin, the three apical segments of abdomen with a slightly raised smooth carina, last segment triangularly excised.

\$. With lower surface less pulvulose, showing a more coppery and pilose surface, with a smooth spot on the sides of abdominal segments, the apex not excised; head less coppery, basal joints of antennæ blue.

Dimensions : $\$ .24 .5 \times 8 ;$ ㅇ. $25 \times 8 \frac{1}{2} \mathrm{~mm}$.

Hab.-Cue, West Australia (H. W. Brown).

The facies and sculpture of the upper surface are very like those of Chalcophorella Beltance Blackb., or C. exilis Blackb.; but it is a much larger and more varicolored insect than these, while the distinct abdominal costa (wanting in Chalcophorella), and the somewhat longer antennæ point decidedly to Chalcotcenia as its.place. A marked character in this species is the almost total absence of the usual posterior denticulation of the elytra. Only by a close examination, can the very slight apology for this be observed. Type in author's Collection.

Buprestis mesta, n.sp.(?)

Oval, nitid; head and pronotum dark violet, front of the former sometimes interspersed with copper, elytra entirely blue-black, underside blue or dark green, legs and antennæ violet or blue. 
Head coarsely dentate, with a short carina between eyes, and a triangular impression on epistoma. Prothorax as in B. 10-notata L. \& G., widest at base, sides nearly straight, slightly converging to apex, front angles depressed and obtuse (from above), posterior acute, disc with a wide medial sulcus, and two large basal foveæ, irregularly punctate. Scutellum small, transverse. Elytra as wide as prothorax, and thrice and one-half as long, widened behind middle, apex trispinose, outside and sutural spines short and sharp, the middle blunt and rounded; striate-punctate, the striæ forming deep sulci at apex and sides, showing the punctures more than in $B$. decemnotata, intervals convex and punctate underside very lightly and shortly villose, and finely punctate. Dimensions: $13.5-15 \times 4.5-6 \mathrm{~mm}$.

Hab.-Dorrigo, New South Wales (W. Heron).

I have received five specimens of this, which may very well be only a melanic variety of the well known B. decemnotata $\mathrm{L}$. \& G., (=B. aurantiopicta L. \& G ?). I have, moreover, a specimen from Queensland (Mr. R. Illidge), which is similar to the above except in showing a small indication of a red mark on the 7 th interval behind the middle; but the apex of the elytra differs from that in six specimens of $B$. decemnotata before me [which agree with Saunders' figure in being bispinose, not truncate, as in his description (Trans. Ent. Soc., 1868, p.7)]. In the $\delta$, the apex of abdomen is truncate; in the $Q$, oval. Types in the author's Collection.

Note.-In one of my six specimens of B. 10-notata, the two postmedial spots are confluent, forming a short fascia, as in the figure of B. aurantiopicta given by Laporte \& Gory, and oddly enough also in that of B. 10-notata.

\section{Bubastes formosa, n.sp.}

Cylindric, nitid, and glabrous; head (on forehead only), pronotum, and elytra a rich blue (in one example, the elytra somewhat greenish); epistoma, mouth, antennæ, and a triangular patch on apex of forehead, sides of prothorax, sides and apex of elytra, together with the underside and legs, brassy; (the sides of elytra less nitid than the rest, and, towards the apex, rather red than brassy). Scutellum green. 
Head coarsely and closely punctate, a sulcus between eyes, widening into an elongate smooth space. Prothorax $4 \times 5 \mathrm{~mm}$., bisinuate at apex and base (more feebly so at apex), widest near base, sides feebly rounded and converging anteriorly, nearly straight posteriorly, front angles obtuse and declivous, posterior angles (seen from above) rectangular; disc coarsely punctate as on head, becoming coarser, with a tendency to latitudinal confluence towards base, a smooth medial line terminating in a fovea near base, lateral carina short, not visible from above. Scutellum circular, with a depressed area behind it. Elytra of same width as prothorax, and more than thrice as long, rather deeply striate near suture, less deeply at sides, punctures coarser than in B. inconsistans Thoms., two or more rows of punctures crowded in the striæ, and sometimes overflowing on the raised intervals; anterior portion of elytra slightly rugulose, apex obliquely bispinose, sutural spine longest, sides crenate near apex; underside very coarsely punctate on prosternum, less coarse on meso- and metasternum and legs, on abdomen becoming finer towards apex, last segment rugose, metasternum sulcate. Dimensions : $16-18 \times 5 \cdot 6 \mathrm{~mm}$.

Hab.-Cue, West Australia (H. W. Brown).

I am indebted to Mr. Brown for two male specimens of this most beautiful species of the genus. It differs widely in colour alone from all described species. Type in the author's Collection.

\section{Bubastes suturalis, n.sp.}

Cylindric, brilliantly nitid, glabrous above, shortly albispilose beneath. Head green or coppery, prothorax brassy on disc, green at sides, elytra gold or coppery shading off to green laterally, with the sutural interval blue or violet, basal margin blue or green, underside and legs bright green, antennæ and tarsi coppery-red, scutellum blue.

Head concave and sharply striate between the eyes, coarsely punctate, more sparsely so than in $B$. formosa, and not at all rugose. Prothorax (in $\$, 3.5 \times 5.5 \mathrm{~mm}$.) more narrowly convex than usual, apex feebly, base strongly bisinuate, sides feebly widened, arcuately converging anteriorly, front angles rounded, 
posterior angles acute (as seen from above); punctures on centre and apex much smaller than on head, becoming coarser at base, and transversely rugose at sides, the punctures more sparse than in B. formosa, without definite medial line, except that indicated by a deep elongate fovea near base. Scutellum circular, depressed and concave; punctate. Elytra of same width as prothorax at base, and more than thrice as long, each elytron bispinose at apex, in $\delta$ the spines of nearly equal length, the excision between them semicircular, in $q$ the apical spines obsolete or blunt; striate, with about three rows of punctures crowded between the intervals, the punctures larger than in $B$ inconsistans Thoms., and smaller than in B. formosa, the intervals little raised, nitid and almost impunctate, becoming obsolescent at apex; underside coarsely punctate, the punctures becoming gradually finer from sternum to apex of abdomen. Dimensions: $\$, 12 \times 4 ;$,, $17 \times 6 \mathrm{~mm}$.

Hab.-Drysdale River (H. Giles), Cue (H. W. Brown).

Three specimens examined. B. splendens Blackb., seems near it, but is described as green, with base of head and antennæ violet. B. aureocincta Blackb., while differing in colour, has evidently a very differently shaped prothorax. Type in the author's Collection.

Neocuris Brownit, n.sp.

Ovate, nitid, head and prothorax of $\delta$ blue, the latter with base and sides greenish, of $q$ brilliant brassy-green; in both sexes the scutellum green, elytra yellow, with basal margin green, the suture and sides narrowly dark violet, underside, legs, and antennæ metallic green.

Head wide, not deeply received into prothorax, concave between eyes, finely and closely punctate. Prothorax widest at base, gently and roundly converging from base to apex; truncate at apex, bisinuate at base, anterior angles obtuse, posterior acute (both viewed from above); closely punctate as on head, without medial line, a shallow oblique impression on each side extending from apex outwards, and a transverse triangular basal fovea near hind angles. Scutellum small, transversely oval, smooth. Elytra not covering apex of abdomen, of same width as prothorax at 
base, separately rounded behind, obscurely impressed near shoulder; finely punctate-striate; underside closely punctate. Dimensions : $6-7 \times 2 \frac{1}{4}-2 \frac{1}{2} \mathrm{~mm}$.

Hab. -Cue, West Australia (H. W. Brown).

A pair, the sexes, form another of Mr. Brown's interesting captures in this district. The species is very near $N$. discoflava Fairm., but the head and pronotum are bright metallic, without the coppery margin, the elytra with much narrower dark edging, the yellow extending almost to apex, the head is more tumid and less enclosed in the prothorax than in Fairmaire's species, with the underside different. Type in the author's Collection.

\section{Stigmodera immaculata, n,sp.}

Oblong-ovate; head, antennæ, prothorax, scutellum, underside, and legs, of $\delta$, bright metallic green; of o, rich golden-coppery, elytra (in both sexes) pale yellow; underside sparsely clothed with short white hair.

Head finely punctate, with a shallow excavation between eyes. Prothorax narrow, apex truncate, base bisinuate, sides straightly converging from base to apex, anterior angles unseen from above, deflexed and embracing the head, posterior angles subacute; disc finely and closely punctate in front, more coarsely so at base, medial line impressed only near base, two small basal foveæ. Elytra of same width as prothorax at base, and about twice and one-half as long, with moderate posthumeral and postmedial enlargements, rounded at apex, with a small circular excision bounded externally by two short sharp black spines, sides near apex entire; striate-punctate, intervals convex and finely punctate, apex of abdomen truncate in $\hat{\delta}$, rounded in of; underside finely punctate, prosternum, especially the sides, more coarsely punctate. Dimensions : $8 \times 3.5 \mathrm{~mm}$.

Hab.-Cue, West Australia (H. W. Brown).

Of the S. sexguttata Macl., (S. puella Saund.), and S. dispar Blackb., type, but larger and wider than Macleay's species, and the elytra without any markings. Two specimens, the sexes, received from Mr. Brown, who states that the sexual coloration is constant. The shape of the prothorax is unusual, narrow and 
subconic, with its anterior part of the same width as the head. S. dispar Blackb., (from Queensland) has a very differently shaped prothorax, inter alia. Type in the author's Collection.

Stigmodera.-I have unfortunately used two preoccupied names in describing my species, and would, therefore, note the following alterations.

S. caudata Cart., = S. Hackeri Cart.

Kerremans has utilised the name caudata (Soc. Ent. Belg., 1900, p.316).

S. gracilis Cart., $=S$. gracilior Cart .

The name gracilis was used previously by Castelnau and Gory for a Brazilian species, since transferred to Conognatha.

Nascio. - When describing two new species (These Proceedings, 1912, pp.482-3), I had not then read Mons. Kerremans' work in the Genera Insectorum, and hence did not note his division of the genus, a division entirely satisfactory, and, indeed, necessary. In accordance with this, Nascio Tillyardi Carter, belongs to the new genus, and should be known as Nascioides Tillyardi Cart. The learned author has inadvertently omitted Nascio chydoea Oll., Nascioides munda Oll., and N. multesima Oll., from that work. 


\section{$2 \mathrm{BHL}$ Biodiversity Heritage Library}

Carter, H. J. 1915. "Descriptions of six new species of Buprestidae." Proceedings of the Linnean Society of New South Wales 40, 76-82. https://doi.org/10.5962/bhl.part.18864.

View This Item Online: https://www.biodiversitylibrary.org/item/30116

DOI: https://doi.org/10.5962/bhl.part.18864

Permalink: https://www.biodiversitylibrary.org/partpdf/18864

\section{Holding Institution}

MBLWHOI Library

\section{Sponsored by}

MBLWHOI Library

\section{Copyright \& Reuse}

Copyright Status: NOT_IN_COPYRIGHT

This document was created from content at the Biodiversity Heritage Library, the world's largest open access digital library for biodiversity literature and archives. Visit BHL at https://www.biodiversitylibrary.org. 